\title{
The strength of green ties: Massachusetts cranberry grower social networks and effects on climate change attitudes and action
}

\author{
Brian J. Gareau ${ }^{1}$ (D) Xiaorui Huang $^{1} \cdot$ Tara Pisani Gareau $^{2}$ (D) $\cdot$ Sandra DiDonato $^{1}$
}

Received: 6 January 2020 / Accepted: 27 July 2020 / Published online: 11 August 2020

(C) Springer Nature B.V. 2020, corrected publication 2020

\begin{abstract}
The cranberry, a commodity of social, cultural, and economic importance to New England, is under threat due to climatic change in this region of the United States. Yet, previous research reveals that cranberry growers have mixed attitudes about the anthropogenic roots of climate change, with many being skeptical. Building on the researchers' analysis of the personal and ecological conditions that affect climate change attitudes among cranberry growers, this paper examines the effect that key actors in the growers' social networks have on those attitudes. Through statistical analysis of survey data and content analysis of two important cranberry newsletters, the paper finds that cranberry growers' perceived importance of two key cranberry growing institutions, the "sociopolitically focused" Cape Cod Cranberry Growers' Association and the "technically focused" University of Massachusetts Cranberry Station, as well as connections to other cranberry growers, is associated in nuanced ways with growers' climate change attitudes. Drawing on the sociological theory of "social capital," the paper examines how these social ties to key actors/institutions may result in greater threat perception or worry about climate change. It then considers how "green ties," if harnessed and supported by these important actors in the cranberry grower network, might significantly mitigate climate change in the future.
\end{abstract}

Keywords Agriculture $\cdot$ Cape Cod·Climate action·Climate change $\cdot$ New England $\cdot$ Social capital - Social networks

Electronic supplementary material The online version of this article (https://doi.org/10.1007/s10584-02002808-0) contains supplementary material, which is available to authorized users.

Brian J. Gareau

Brian.gareau@bc.edu

1 Department of Sociology, Boston College, Chestnut Hill, MA, USA

2 Department of Earth and Environmental Sciences, Boston College, Chestnut Hill, MA, USA 


\section{Introduction}

One of only a few fruits native to North America (Agricultural Marketing Resource Center 2019), the cranberry (Vaccinium macrocarpon) is an iconic symbol of the New England region of the United States, even serving as a symbol of one of the earliest holidays celebrated in the English Colonies-Thanksgiving (also among the very first officially declared U.S. holidays, see Straus 2014). Americans consume nearly 400 million pounds of cranberries per year, 20\% of them during the Thanksgiving holiday (Cape Cod Cranberry Growers' Association 2020). Massachusetts was home to the original cultivators of cranberries and is currently the second largest producer in the United States, at almost 2 million barrels per year in 2018, behind Wisconsin, which harvests over 5 million barrels per year (Keough 2018).

For Massachusetts, the cranberry holds deep cultural and historical importance. The Cape Cod region in particular, where most Massachusetts cranberries are grown, contains a geographic patchwork landscape in which cranberry bogs are an intricate part of social life. Many people in the region know something of the long history of New England geography during which receding glaciers formed cavities in the land that ultimately formed kettle ponds filled with the sandy acidic soils ideal for cranberry vines to thrive. Likewise, many have learned how the Wampanoag (an indigenous group whose culture and history is often part of educational programs in the Massachusetts public school system) first used the cranberry some 12,000 years ago, and how European settlers took it up in the sixteenth and seventeenth centuries, before finally transplanting and cultivating it in the early 1800s (Playfair 2014). The Cape Cod Cranberry Growers' Association (CCCGA) was founded in 1888, making it one of the oldest growers' organizations in the country (Cape Cod Cranberry Growers' Association 2020). By 1900, cranberries were a widely known and profitable commodity (Cape Cod Cranberry Growers' Association 2019). During harvest, the bogs are transformed into seas of red berries, the beauty of which has been noted by Henry David Thoreau and others. Today, the Cape Cod region attracts tens of thousands of tourists who take cranberry bog tours and attend any number of cranberry harvest festivals held throughout the Cape Cod region.

The cranberry, however, as an agricultural commodity is under dire threat from global climate change. With temperature increases of $2-5{ }^{\circ} \mathrm{C}$ expected by the end of this century in the Northeastern United States, the extremely temperature-sensitive cranberry - native only to North America - is in danger of becoming unprofitable. In many ways, the cranberry is a hardy plant; the vines can stay productive for over 100 years. Evolving with the predictable temperatures/climate of New England, they need full sun in the summer months, cool temperatures when the fruit is maturing, and cold winters. Not only can they survive winters completely covered by water and ice, they in fact require a certain number of hours below freezing to bear fruit. They also depend on an abundant supply of water at various points of the year for protection against frost and pests. Ideally, cranberries need roughly 62 days with temperatures below $45^{\circ} \mathrm{F}$, but with global warming this is becoming increasingly uncertain. Fewer cold days can lead in some cases to abnormal blossoming, which could reduce yields by $50 \%$. Milder and shorter winters will also likely increase winter survival of cranberry pests, such as the cranberry weevil and winter moth. Such warmer winters are now anticipated across New England, where even Maine is estimated to have only half of its current annual snowfall by the end of the century (Armstrong 2016). The estimated increase in extreme heat days will also stress cranberry plants. Northeast U.S. cities are expected to experience up to 60 more days reaching $90^{\circ} \mathrm{F}$ than they do at present by the end of the century. Projected warmer, earlier springs will lead to earlier bud swelling, exposing them to more potentially fatal frost events; 
later, warmer summers will occasion berry scalding, injuring the fruit and causing poorer color and therefore marketability; hotter summer temperatures will also lead to vine and flower stress along with potential die-off of pollinating insects such as honey and native bees that are critical to cranberry flower pollination. Estimated increases in intense rain events in the summer will lead to higher levels of fruit rot, lower levels of budding (because of flowers lost to rain or hail), lower pollination levels, and less bee activity (Gareau et al. 2018).

Given the significant threat that climate change poses for their crop, it is important to discern how prepared cranberry growers are to recognize and respond to the danger. Research results reported in Gareau et al. (2018) demonstrate that there is a complex relationship between the personal and ecological conditions of cranberry growing and attitudes toward climate change among Massachusetts cranberry growers. Some conditions (discussed more thoroughly below) appear to create spaces in which actions on climate change might emerge, such as among growers who think weather is an important problem facing the cranberry industry. The search for connections between attitudes and certain conditions among growers, and whether certain social networks foster concern and action against climatic change, is a central question in this paper. In this, our research draws from the literature on grower attitudes toward climate change and literature focusing on the effects that powerful actors in social networks can have on attitudes and actions of people in the network. Are there ways in which social networks among cranberry growers are arranged that allow for climate change to be seen as a concern? Using a survey disseminated to the entire Massachusetts cranberry grower community, examining the newsletters of two key cranberry organizations, and drawing from our decades of combined knowledge of the Massachusetts cranberry growing industry, this paper seeks to answer this question.

\section{Literature review}

\subsection{Grower attitudes toward climate change}

Scholarship in the social sciences aims to understand the attitudes that growers in the United States hold toward climate change, and particularly, whether certain social and economic conditions might connect to greater levels of awareness and concern. While grower attitudes vary across regions and circumstances, most studies report high levels of awareness of environmental changes and extreme weather events that affect farming, yet acknowledgement of its anthropogenic causes is less common (Chatrchyan et al. 2017). Even in the organic sector, where it might be assumed that growers hold environmental values above their conventional counterparts (Fitzmaurice and Gareau 2016; Jackson et al. 2011), attitudes toward climate change can be unexpected. Research shows that conservative white male growers tend to be less concerned about climate change and are less likely than other social groups to believe it is occurring, which is consistent with the broader trend among U.S. citizens (Liu et al. 2014; McCright and Dunlap 2011; Running et al. 2017). In short, there is no particular sector or grower group that appears more attuned than another to the threat of climatic change and the need to act.

Since, on the whole, U.S. growers are less concerned about climate change and more skeptical of climate change science than average U.S. citizens, it is particularly important to frame local weather events and other conditions in a broader context that triggers interest among growers (Chatrchyan et al. 2017). Discussing the increased likelihood of extreme 
weather events and temperature variability and their effects on particular sites due to climatic change will help with mitigation and the adoption of climate-resistant strategies. In other words, framing the issue in a way that makes sense to the daily lives of growers will increase the likelihood of implementing climate adaptation strategies. The notion of framing discussions of climatic change in ways that are sensible to the local context suggests the importance of achieving trust and rapport among the stakeholders involved in the framing process as well as creating communal conditions that foster 1) an awareness of climatic change as a serious threat to local ways of life, and 2) the adoption of climate mitigation and adaptation strategies specific to the local context. If growers are involved in social networks that include experts that they trust, whose knowledge of farming and other matters they respect, the more likely they will be to listen to and incorporate the experts' knowledge in their own decision-making. This establishment of trust is often described in sociology as the development of social capital.

\subsection{Social capital, communal conditions, and small-scale farming networks}

Social capital refers to the persistent, long-term connections that exist between social actors in a network, leading to acts of reciprocity, the sharing of norms, and collective action to resolve social and ecological problems (Ostrom 2000). Social capital "has explanatory power specifically in the area of collective action for environmental management" (Adger 2003: 389). From responding to specific ecological disasters to gathering resources to cope with longstanding economic hardship brought on by environmental degradation, these social connections are consistently identified as important for garnering support to work toward improvements in social welfare. As a theoretical frame, social capital "provides an explanation for how individuals use their relationships to other actors in societies for their own and for the collective good" (Adger 2003: 389).

Social capital has been used to understand how innovations have emerged in smallscale farming scenarios worldwide (Lowitt et al. 2014). It is often used to conceptualize how social ties among actors may make up for poorly designed development practices in the Global South, or to make up for the fragility of weak institutions among impoverished peoples and communities (Fafchamps 2006; Lowitt et al. 2014; van Rijn et al. 2012). In such cases, the connections among actors are seen as providing decentralized planning in lieu of the policy implementation that can be enforced by a powerful centralized body such as a local or regional governmental institution (Bodin and Crona 2009; Crona and Hubacek 2010). When examining the role of social capital in the adoption of farming adaptation methods (e.g., conservation technologies, services, programs), it becomes clear that the results reflect disparities among the factors leading to successful implementation. This could be attributed to various causes, such as the use of different methods and models when collecting and analyzing data, or the location/region of the study. Some variables are found to be rather universally significant, however, such as the presence of extension services and farming associations (see Deressa et al. 2009; Takemura et al. 2014; Hoang et al. 2006).

While climate attitudes among growers, such as worry and threat perception, are important, this paper also examines how social networks might contribute to the implementation of climate adaptive cranberry growing practices. Grower associations make up a form of social capital found to be highly significant; the diffusion of new technologies and practices is typically linked to membership in agricultural organizations (Yaméogo 
et al. 2018). For example, in a synthesis report covering over 30 years of research on growers' adoption of conservation agriculture, involvement in private and governmental associations was found to be an important social tie, the most consistently positive variable (Knowler and Bradshaw 2007). As Adger (2003) argues, the achievement of adaptation strategies must be based on social capital understandings of trust, reciprocity, and shared norms in order to alter perceptions of climate change as being inconsequential.

While the majority of studies have focused on the positive effects of harnessing social capital, there are negative aspects associated with it as well, including the swaying of deliberations on environmental policy choices in global agreements due to uneven access to powerful actors via vertical capital (Gareau 2010) and uneven access to natural resources among networked groups (Ballet et al. 2007). As such, social capital can create shared beliefs and a knowledge production platform that undermines what ethicists describe as the "common societal good" (van Deth 2010; Hollenbach 2002).

\subsection{Social capital and communal conditions of production}

The combination of positive and negative aspects of social capital highlights the importance of recognizing that these social ties of influence are situated in the personal, communal, and ecological conditions of the grower (Gareau 2008; Gareau et al. 2018; White et al. 2017). The ties that allow for social capital to be constructed are enmeshed in the communal conditions of growers, in that "communal conditions provide the social framework in which actors operate, where norms of sharing advice, equipment, access to water in adjacent wetlands, and other resources can be created to allow livelihoods to persist even in difficult situations" (Gareau et al. 2018). Here, growers' views of climate change might depend in part on the cultural fabric of the cranberry community, where the ideas of powerful actors are able to shape, frame, and influence attitudes and thereby encourage certain actions (Cf. Lucier and Gareau 2015; Olson and Gareau 2018).

Our concern in this paper is whether ties to certain social actors have produced any level uniform "belief" among the overall cranberry grower community regarding what the scientific community understands to be a fact: anthropogenic climate change (National Research Council 2010). More specifically, can the social ties that connect important social actors in a network work to induce a high level of concern about the threat of climatic change among growers? Does a grower's social network have an effect on their attitudes and the kinds of practices they engage in? Here, we are looking for social connections that might constitute "green ties," ties that encourage growers to perceive the threat of climatic change as palpable, in the hope that such awareness will translate into collective action on the local level through adoption of mitigation and adaptation techniques (Adger 2003). In this, our study joins Bourdieusian scholarship on social capital, which focuses on the perceptions of the importance (or influence) of actors, processes, or mechanisms in a network, perceptions that provide insights into the makeup of social ties in a network (e.g. Bourdieu 1985; Sanginga et al. 2007; Pretty 2003; Jones et al. 2009). If such an attitude among this social group has emerged, we can say that the communal conditions of cranberry production are right for collective action on the local level. Conversely, if low concern about the threat of climatic change is evident, local engagement with its solutions is unlikely. 


\section{Case study: cranberry production and the cranberry community}

Work on social capital stresses the influence that certain powerful actors have on the social networks in which they are embedded. Those with influence can shape what is deemed important to the network of actors and influence the communal conditions of production of those operating in that network. ${ }^{1}$ We apply this theoretical frame to the case of cranberry production in Massachusetts. In Massachusetts, cranberry growers are connected to a range of organizations that exist to support and sustain the cranberry industry. The result is a tightly knit community in which production and livelihood are intimately fused together. Organizations with important social ties to cranberry growers include the University of Massachusetts (UMass) Extension program and the UMass Cranberry Station in particular, the Cape Cod Cranberry Growers' Association (CCCGA), the cranberry cooperative Ocean Spray, and other cranberry handlers. Also making up the communal conditions of production are cranberry growers' involvement with one another through family ties, grower meetings, the annual Cape Cod Cranberry Harvest Festival, their pest control advisors, and similar connections. The social links that growers develop with one another provide powerful ways of sharing knowledge and other forms of support among themselves. Yet, social capital research points to the importance of the social ties made through connections to influential actors outside the personal relations of individuals, whether these are state or non-state organizations, in establishing certain "ways of knowing" within the social network (Adger 2003). Do certain social ties in the social network of the cranberry growers' community foster greater concern for climate change among them than among other socially networked growers? Do some social network connections increase recognition of the threat that scientifically predicted climate change poses to the cranberry grower community? If so, does that recognition lead to collective action in the form of specific management practices to mitigate climate change?

While to our knowledge no study has been conducted on the communal/social networks of Massachusetts cranberry growers, previous research reveals how cranberry growers' attitudes toward climate change are tied to their personal and socio-ecological context. Gareau et al. (2018) find that Massachusetts cranberry growers' attitudes toward climate change are not only affected by their personal conditions but are also contextualized by the ecological and communal conditions of cranberry production. With regard to personal conditions, the authors find that cranberry growers who identify as women and those who have college degrees are more likely to view climate change as a threat and to worry about it. With regard to ecological conditions, cranberry growers who report weather in general as an important condition are more likely to see climate change as a threat. However, attitudes toward climate change are more varied when growers single out individual weather conditions for consideration. For example, identifying insufficient chill hours during winter (a climatic change in New England that is particularly damaging to cranberry production) is positively associated with the likelihood of seeing climate change as a threat and worrying about it. The fact that there is little growers can do to compensate for the insufficient chill hours may well account for this view. Growers can regularly irrigate their cranberry bog, which helps reduce the risk of frost when cranberry plants break dormancy too early during an insufficiently or inconsistently cold winter, but this is a laborious and water-intensive operation and does not solve all the problems caused by insufficient chill hours.

\footnotetext{
${ }^{1}$ In this theoretical engagement, we draw from the extant literature as well as previous work of the authors. (Please see Gareau 2012, 2013; Gareau et al. 2018.)
} 
Gareau et al. (2018) argue that to cope with the warming winter temperatures, cranberry growers will need to increasingly rely on their communal networks (i.e., communal conditions of production) and their sponsorship of such measures as the development of new cranberry varieties with higher frost tolerance and requiring fewer chill hours. Influential actors might tap growers with higher levels of climate awareness to increase awareness among the cranberry grower community. On the other hand, Gareau et al. (2018) find that perceptions of water scarcity and competition for water are not associated with climate change attitudes among cranberry growers, perhaps because of the growers' long history of collectively coping with the variable precipitation levels that are typical in New England (Playfair 2014). In any case, cranberry bogs are highly resistant to drought and flooding, so it is quite possible that cranberry growers would take longer to identify changes in these ecological conditions as problematic. Gareau et al. (2018) also find that control of certain ecological conditions of production is associated with climate change attitudes: An increase in the acreage of wetland habitat owned by the cranberry grower increases the odds of worrying about climate change, while an increase in upland habitat owned reduces those odds. Gareau et al. (2018) speculate that this may be because ownership of wetland habitat prompts cranberry growers to be more attuned to the impacts of climatic change on the water resources in these habitats. Contrastingly, ownership of dry upland habitat, by allowing for other forms of agricultural production and other money-generating activities such as selling sand and gravel, may offer a protection against, and reduce attention to, the climate impact on cranberry production.

While Gareau et al.'s (2018) work shows the connections between climate change attitudes and personal and ecological conditions among Massachusetts cranberry growers, it remains unknown whether certain networks of actors create higher levels of climate awareness among community members. Are there certain socially networked actors who contribute to higher awareness levels among cranberry growers? In other words, are certain communal conditions of production - influenced by the social ties of particular actors-leading some cranberry growers more than others to greater awareness and/or concern, and are some growers engaging in practices to mitigate the effects of a warming climate?

Based on several years conducting social and ecological research in and around the cranberry industry, conducting in-depth interviews with cranberry growers, cranberry extension agents, and other members of the cranberry community, the authors determined that it would be useful to study the scientific community and institutional actors operating to provide scientific and other forms of support to the cranberry industry in Massachusetts and their influence on the attitudes of cranberry growers. These actors, functioning as advisors on scientific matters, on practical issues such as pest outbreaks, and on the political, economic, and legislative issues concerning the industry, communicate their knowledge about the cranberry industry to growers in three important ways: 1) personal communication with growers, 2) dissemination of updates and reports via monthly newsletters, and 3), more distantly, through public statements given in the local media by the leaders of these organizations.

As an extension agency mandated to help cranberry growers thrive in their industry, the UMass Cranberry Station communicates with growers at the personal level, through annual and seasonally held conferences and workshops, and through updates provided in their monthly newsletter, the Cranberry Station Newsletter. The CCCGA is a growers' association also created to assist cranberry growers in their production, but they provide information more focused on the broad grower environment and "business" sides of the industry, giving updates on the state of the industry, political and regulatory updates, and the like through their monthly 
newsletter, Bogside. While Ocean Spray and other cranberry handlers are also institutions that likely impact cranberry growers' knowledge frames, we limited our focus to the UMass Cranberry Station and CCCGA. We did this because 1) both groups operate outside the industry per se, meaning their interest is not first and foremost advancing profits and sales, but instead offering agricultural information relevant to cranberry growing; and 2) both groups publish monthly newsletters addressed to growers - affording us a second method with which to understand how social ties to these two organizations might be significant in shaping climate attitudes among their readership. ${ }^{2}$ The use of this "mixed methods" approach helps add validity to the findings that are achieved in one analysis by allowing for results to be compared to those of a different, yet complementary, method of inquiry (Hesse-Biber 2010).

\section{Methods}

In order to examine the effect of important social ties among actors in the cranberry grower network, we employ two primary research methods: statistical survey analysis and content analysis of monthly newsletters.

In 2016, two of the authors (Gareau and Pisani Gareau) solicited all of the Massachusetts cranberry growers to participate in a survey. Grower contact information was provided by the UMass Cranberry Station, and CCCGA sent the solicitation to its members. Growers were either emailed the solicitation or saw it posted as an advertisement in the CCCGA monthly newsletter, Bogside, throughout the year. The researchers mailed hard copies of the solicitation, along with the survey and postage-paid return envelopes, to all growers on the CCCGA mailing list who had not returned the survey. Grower contact information was not released, in order to protect the privacy of CCCGA members. The online consent form explained the nature of the study prior to answering questions, and a hard copy of the consent form was provided as part of the survey form. The research complies with ethical practices and was approved by the Boston College Institutional Review Board (Protocol number 12.139.01e) prior to disseminating the survey. The researchers received 91 responses out of roughly 400 cranberry growers, or $23 \%$ of the grower population, making this is an adequate sample size with a sampling error of \pm 5 to $\pm 10 \%$ at the $95 \%$ confidence level (Salant 1994) for this particular group. (See Gareau et al. 2018 for further details.) As reported in Gareau et al. (2018), "the sample reflects a large portion of total cranberry acreage in Massachusetts (over $40 \%$ ), and roughly $20 \%$ of upland habitat owned by cranberry growers" (p. 8). It is important to note that none of the authors are affiliated with CCCGA or the UMass Cranberry Station.

Actors at both the UMass Cranberry Station and CCCGA use monthly newsletters to communicate with cranberry growers and disseminate information and views on issues pertinent to growers, with the goal of helping them in their production pursuits. As we discuss below, each of these organizations has a mandate and mission that both governs the content of the newsletters and shapes how issues are framed and disseminated. Examining the newsletters will therefore reveal how influential knowledge passes via this social tie to the cranberry growing network. If the newsletter of an influential actor discusses climate change and associated issues that impact cranberry growing, for instance, we would anticipate the

\footnotetext{
${ }^{2}$ Additionally, in unreported analyses of the survey data used here, we have found that growers' views regarding cranberry handlers as important members of their social networks show no relation to growers' attitudes toward global warming or their management practices in cranberry production.
} 
cranberry growers in that network will have higher levels of concern about climate change. Finally, we also search for references to climate change in media stories featuring key actors in these two organizations, and again, we examine the framing used to present them.

While the frequency of social interactions among growers and the CCCGA and UMass Cranberry station is imprecise in the survey data, our understanding of the industry as researchers gives us confidence to consider the connections between these organizations and the growers influential, based on the fact that the growers identify their connections to these organization as important. Growers have ample opportunities besides the monthly newsletter to interact with the UMass Cranberry Station throughout the year at workshops and field days, requested visits to growers' bogs, and the annual meeting to review the cranberry harvest. For CCCGA, in addition to the monthly newsletter, growers receive announcements about issues of concern. For example, since publishing the April 2020 issues of Bogside, the CCCGA has issued two "Grower News Alert" updates on COVID-19 to help growers navigate the federal Paycheck Protection Program (PPP) and the Economic Disaster Injury Loan (EIDL) program, as well as posting links for webinars to help growers through the pandemic. Therefore, while exact frequency data are lacking, we accept that connections to these organizations are important when growers say as much; and if a pattern of attitudes among growers emerges in concert with their expressed importance, the results will be instructive.

\subsection{Statistical analysis: survey}

First, we lay out the statistical analysis of the survey. We conducted statistical analyses using data gathered from the survey of cranberry growers.

\subsubsection{Dependent variables}

We model two sets of dependent variables. The first set includes two variables on attitudes toward global warming: global warming threat and global warming worry. Both variables are used in Gareau et al. (2018) to capture cranberry growers' global warming attitudes, and are also consistent with measures used by Chong (2014), Dunlap et al. (2016), and McCright et al. (2014) to study climate change attitudes in the United States, among many other studies. Global warming threat is a binary variable operationalized using cranberry growers' responses to the survey item "Do you think that global warming will pose a serious threat to you or your way of life in your lifetime?" ( $1=$ yes, $0=$ no). Global warming worry is an ordinal variable capturing growers' responses to the survey item "Please tell us how much you personally worry about global warming" (a 1 to 4 scale: "not worry at all" to "worry a great deal").

The second set of dependent variables includes three variables on the management practices growers implemented in cranberry production that are related to climate change adaptation and mitigation. The first variable, management practices count, measures the number of management practices that cranberry growers reported to have implemented in their bogs in the past 510 years. In the survey, we asked growers: "Which of the following management practices have you implemented on your bog in the last 5-10 years?" Growers were to select all that applied from a list of practices we provided, including integrated pest management, sanding, late water, "smart" irrigation and/or frost alarm, organic amendments, conservation or creation of pollinator habitat, and other. Respondents who chose "other" were invited to elaborate on their responses in the survey; we then recoded these into three additional categories: water recovery, other1, and other2. "Water recovery" was supplied by several respondents as an 
answer in the "other" category; "other1" and "other2" denote idiosyncratic explanations of the "other" category that are unique to specific respondents, which we recoded in this way to account for them in management practices count. We also model one dependent variable on a specific management practice, pollinator habitat conservation, which is a binary variable capturing whether growers have implemented pollinator habitat conservation in the past 5 to 10 years $(1=$ yes, $0=$ no). Cranberries require animal pollination to set fruit (Armstrong 2016). With global findings of biomass and biodiversity loss amongst insects and other pollinators due to environmental degradation and climate change, and with continued threats of parasitism and disease among honey bees (Apis mellifera L.) commercially managed for agricultural pollination, this management practice is essential for the continued sustainability of cranberry production. The third variable, management practices importance, captures growers' responses to the survey item, "On a scale of 1 to 5 , have some or all of these management practices become more important over the past 5 to 10 years?" (a 1 to 5 scale: not important to very important). Only three respondents chose "1" (not important) or "2" (minimally important). Therefore, we elected to recode the responses into three ordered categories: somewhat important or less (including minimally important and not important), important, and very important.

\subsubsection{Key independent variables: communal conditions of the social network}

In the survey, we asked growers to indicate whether each of the three actors potentially tied to their social networks - the CCCGA, UMass Extension, and other cranberry growers - had been "important" to their cranberry operation from 2010 to present. While not the focus of this paper, in-depth interviews with cranberry growers reveal that these three actors are important for a variety of reasons related to gaining knowledge on cranberry growing techniques, practices, pest outbreaks, and the like. For example, one grower told us that growers would often convene at the UMass Cranberry Station in Wareham, MA, to collaborate on addressing common problems such as weed control and share their latest inventions. (The industry is so small, growers often make their own equipment and share the designs.) Again illustrating the importance of both fellow growers and the UMass Cranberry Station, another grower told us how they and their father "frequently went to the UMass Cranberry Experiment Station for advice, camaraderie, and conversation. And if growers had a problem, the UMass Station would send people to the bogs to help the growers free of charge" (pers. comm.). Interviews with growers at the 2017 Cranberry Harvest Festival, held in Wareham, MA, describe the CCCGA as an important actor that promotes both the tradition and modernization of cranberry growing. In particular, growers expressed their appreciation for the CCCGA exhibit "Rhapsody in Red: 200 Years of Massachusetts Cranberries," and how the organization worked to promote the shared relationships among cranberry farms in the wider community. We coded growers' responses into three dummy variables: view CCCGA as important, view UMass Extension as important, and view other growers as important $(1=\mathrm{yes}, 0=\mathrm{no})$.

\subsubsection{Other independent variables}

We also include additional independent variables on growers' ecological and personal conditions of cranberry production that our prior study found to be associated with growers' climate change attitudes (Gareau et al. 2018). Table 1 details the operationalization and summary statistics of each variable. 
Table 1 Descriptive statistics of the overall sample of Massachusetts cranberry growers

\begin{tabular}{|c|c|c|c|c|c|c|}
\hline Variable & Description & Obs. & Mean & $\begin{array}{l}\text { Std. } \\
\text { dev. }\end{array}$ & Min. & Max. \\
\hline \multicolumn{7}{|l|}{ Social network } \\
\hline $\begin{array}{l}\text { View CCCGA as } \\
\text { important }\end{array}$ & $\begin{array}{l}\text { Whether CCCGA has been important to } \\
\text { respondents' cranberry operation from } 2010 \text { to } \\
\text { present. Yes }=1, \text { no }=0\end{array}$ & 91 & 0.82 & 0.38 & 0 & 1 \\
\hline $\begin{array}{l}\text { View UMass Ext. } \\
\text { as important }\end{array}$ & $\begin{array}{l}\text { Whether UMass Extension has been important to } \\
\text { respondents' cranberry operation from } 2010 \text { to } \\
\text { present. Yes }=1, \text { no }=0\end{array}$ & 91 & 0.86 & 0.35 & 0 & 1 \\
\hline $\begin{array}{l}\text { View other } \\
\text { cranberry } \\
\text { growers as } \\
\text { important }\end{array}$ & $\begin{array}{l}\text { Whether other cranberry growers have been } \\
\text { important to respondents' cranberry operation } \\
\text { from } 2010 \text { to present. Yes }=1 \text {, no }=0\end{array}$ & 91 & 0.66 & 0.48 & 0 & 1 \\
\hline \multicolumn{7}{|c|}{ Climate change attitudes } \\
\hline $\begin{array}{l}\text { Global warming } \\
\text { threat }\end{array}$ & $\begin{array}{l}\text { Whether respondents think that global warming } \\
\text { poses a serious threat to them or their way of life } \\
\text { in their lifetime. Yes }=1 \text {, no }=0\end{array}$ & 89 & 0.42 & 0.50 & 0 & 1 \\
\hline $\begin{array}{l}\text { Global warming } \\
\text { worry }\end{array}$ & $\begin{array}{l}\text { How much respondents worry about global } \\
\text { warming, } 1-4 \text { scale from not worry at all to worry } \\
\text { a great deal }\end{array}$ & 90 & 2.21 & 0.89 & 1 & 4 \\
\hline \multicolumn{7}{|c|}{ Management practices } \\
\hline $\begin{array}{l}\text { Mgt. practices } \\
\text { count }\end{array}$ & $\begin{array}{l}\text { Count measure of specific types of management } \\
\text { practices respondents have implemented in their } \\
\text { bogs in the past } 5-10 \text { years }\end{array}$ & 91 & 2.99 & 1.42 & 0 & 7 \\
\hline $\begin{array}{l}\text { Mgt. practices } \\
\text { importance }\end{array}$ & $\begin{array}{l}\text { Rate the importance of management practices in the } \\
\text { past } 5-10 \text { years, } 1-3 \text { scale from somewhat im- } \\
\text { portant or less to very important }\end{array}$ & 85 & 2.27 & 0.71 & 1 & 3 \\
\hline $\begin{array}{l}\text { Pollinator habitat } \\
\text { conservation }\end{array}$ & $\begin{array}{l}\text { Whether respondents have implemented } \\
\text { conservation or creation of pollinator habitat in } \\
\text { their bogs in the past } 5-10 \text { years. Yes }=1, \text { no }=0\end{array}$ & 91 & 0.34 & 0.48 & 0 & 1 \\
\hline \multicolumn{7}{|c|}{ Ecological conditions } \\
\hline General conditions & $\begin{array}{l}\text { Changes in the general conditions for cranberry } \\
\text { growers over the past } 5-10 \text { years. } 1=\text { getting } \\
\text { worse, } 0=\text { not getting worse }\end{array}$ & 89 & 0.70 & 0.46 & 0 & 1 \\
\hline $\begin{array}{l}\text { Weather } \\
\text { importance }\end{array}$ & $\begin{array}{l}\text { Rate the importance of weather-related events in the } \\
\text { past } 5-10 \text { years, } 1-5 \text { scale from not important to } \\
\text { very important }\end{array}$ & 87 & 3.82 & 1.04 & 1 & 5 \\
\hline Weather counts & $\begin{array}{l}\text { Count measure of specific types of weather-related } \\
\text { events severely impacting cranberry production } \\
\text { from } 2010 \text { to present }\end{array}$ & 91 & 2.12 & 1.27 & 0 & 5 \\
\hline \multicolumn{7}{|c|}{ Access to ecological conditions } \\
\hline $\begin{array}{l}\text { Wetland habitat } \\
\text { acreage }\end{array}$ & $\begin{array}{l}\text { Acreage of wetland habitats, top-coded. Unit: } 10 \\
\text { acres }\end{array}$ & 85 & 3.94 & 7.58 & 0 & 30 \\
\hline $\begin{array}{l}\text { Upland habitat } \\
\text { acreage }\end{array}$ & $\begin{array}{l}\text { Acreage of upland habitats, top-coded. Unit: } 10 \\
\text { acres }\end{array}$ & 88 & 10.26 & 17.44 & 0 & 80 \\
\hline $\begin{array}{l}\text { Relative size of } \\
\text { natural habitats }\end{array}$ & $\begin{array}{l}\text { Size of natural habitats as percentage of total farm } \\
\text { size }\end{array}$ & 83 & 67.05 & 19.12 & 0 & 98.40 \\
\hline \multicolumn{7}{|l|}{ Personal conditions } \\
\hline $\begin{array}{l}\text { Educational } \\
\text { attainment }\end{array}$ & $\begin{array}{l}\text { 1-9 scale from No schooling completed to } \\
\text { Doctorate/Professional degree }\end{array}$ & 89 & 6.03 & 1.39 & 4 & 9 \\
\hline Age category & $1-6$ scale from 25 to 34 y.o. to $\geq 75$ y.o. & 90 & 4.18 & 1.16 & 1 & 6 \\
\hline Female & Being female. Yes $=1$, no $=0$ & 88 & 0.24 & 0.43 & 0 & 1 \\
\hline
\end{tabular}




\subsubsection{Modeling techniques}

We estimate a baseline regression model for each dependent variable that only includes three key independent variables on social networks, and we then estimate additional models that control for other independent variables. We estimate logistic regression models for the two binary dependent variables: global warming threat and pollinator habitat conservation. For ordinal dependent variables-global warming worry and management practices importance-we estimate generalized ordered logit regression models. This modeling technique estimates a single coefficient for each independent variable that meets the proportional odds assumption; for each independent variable that violates the assumption, this technique estimates multiple coefficients, one for each cut point of the ordinal dependent variable. This modeling technique is more parsimonious than multinomial models and allows for more flexibility than proportional odds models (Williams 2016). For management practices count, we estimate Poisson models because likelihood ratio tests do not indicate overdispersion. In models that include the important control variables that we identified in our prior study (Gareau et al. 2018), the degrees of freedom are limited due to the small sample size $(N=91)$. Furthermore, we are interested in identifying the aspects of global warming attitudes and management practices that are associated with the three social networks of interest, as well as in the aspects where such associations are absent. Therefore, we elect to use a more lenient alpha level of 0.1 for tests of statistical significance in order to reduce the risk of type II errors (i.e., the nonrejection of a false null hypothesis). We also allow the sample size to vary across models according to the missing data for different combinations of independent variables in each model.

\subsection{Content analysis: newsletters}

We gathered all available issues of the UMass's Cranberry Station Newsletter and CCCGA's Bogside that have been published within the last decade and imported all issues into the NVivo qualitative data analysis package for analysis. ${ }^{3}$ In order to guide our analysis of each organization's respective newsletter, we first examined the mission statements as found on their websites. In both organizations, actors publish newsletter content in line with the values and priorities expressed both in their mission statements and on their webpages.

We performed content analysis in two stages. First we did a "conventional" analysis by reading through all issues, coding loosely for common themes, and creating word clouds to illustrate the most common topics of discussion (Hsieh and Shannon 2005). These findings were then compared with the priorities outlined in each organization's mission statement. Second, we performed a more specific "summative content analysis," which allows for an indepth examination of a topic already determined to be of importance, in this case, climate change (Hsieh and Shannon 2005). The summative content analysis that we employed is focused on the framing and context within which climate change is presented. Framing, "involves the intentional or inadvertent crafting of a message to describe an issue, place responsibility, and/or suggest solutions" (Mossler et al. 2017: 63). To examine the framing of climate change references in the newsletters we first searched for the phrases "climate

\footnotetext{
${ }^{3}$ Given differences in page length and number of issues available for analysis among these two publications, this analysis focuses on the qualitative differences in how these two publications frame and disseminate knowledge.
} 
change" and "global warming"; we considered any use of one of these phrases as a reference to climate change. We also searched for the term "climate" alone and qualitatively determined whether the instance was a reference to climate change specifically or to climate in general. The climate change references were then examined in combination with the "broader meanings present in the data" that were identified during the conventional analysis (Hsieh and Shannon 2005: 1285). In this way, a summative content analysis focused on the framing of climate change can take in the "underlying" and "contextual" meanings that surround climate discourse in these newsletters with specific attention to how climate change is described as an issue, who is responsible for mitigation, and what types of solutions are to be implemented (Mossler et al. 2017).

\section{Findings}

\subsection{Statistical analysis of survey}

Around half of the respondents (46 out of 91) view all three social ties (to the CCCGA, to UMASS Extension, and to other cranberry growers) as important. Only three respondents out of 91 did not view any of the three as important (see Supplementary Table 1). Among the three social networks, we find that the growers who view the CCCGA as important are more likely to consider global warming as a serious threat to their way of life during their lifetimes, compared to the growers who do not consider it an important network, as shown in Table 2, below. This finding holds true even after we control for the variables on personal and ecological conditions of cranberry production that were found in our earlier study to be significant predictors of the perception of global warming as a threat (Gareau et al. 2018: 14-15). According to Model 1, when cranberry growers who do not view the CCCGA as an important network are compared to growers who do value the CCCGA, the odds of the latter group considering global warming a serious threat is about 10 times higher (i.e., $11.349-1=10.349$ ) than the former group $(\mathrm{a}=$ $0.05)$. This positive association is also observed for a smaller sample $(N=74)$ in Model 2 that includes other relevant independent variables, albeit at a different statistical significance level $(\mathrm{a}=0.1)$. In both Models 1 and 2 , the odds ratios for view CCCGA as important are notably larger than those of other significant predictors. This might be because it is a binary variable rather than an ordinal or continuous variable like the other significant predictors (with the exception of female, which is also binary and has the second largest odds ratio in Model 2). Whether a grower values the connection with UMass Extension or with other cranberry growers, however, is not associated with the odds of this grower considering global warming a serious threat.

We also find a positive association between viewing other cranberry growers and UMass Extension as important actors in their social networks and the degree to which growers worry about global warming (see Table 2). Specifically, Model 4 suggests that the odds of being more worried about global warming are 2.4 times greater (i.e., 3.434-1 $=2.434$ ) for growers who view other cranberry growers as an important network compared to growers who do not value other growers as much, holding other independent variables constant $(a=0.05)$. Similarly, the odds of being more worried about global warming for growers who view UMass Extension as an important network are about 4.2 times greater (i.e. 5.184-1 =4.184) compared to growers who do not share this view $(a=0.1)$. 
Table 2 Results of regression models for two dependent variables on global warming attitudes: Massachusetts cranberry growers

\begin{tabular}{|c|c|c|c|c|}
\hline & \multicolumn{2}{|c|}{$\begin{array}{l}\text { Odds ratios of logistic regression } \\
\text { models for global warming threat }\end{array}$} & \multicolumn{2}{|c|}{$\begin{array}{l}\text { Odds ratios of generalized ordered logit } \\
\text { regression models of global warming } \\
\text { worry }\end{array}$} \\
\hline & Model 1 & Model 2 & Model 3 & Model 4 \\
\hline View CCCGA as important & $11.349 * *$ & $18.515 *$ & 1.853 & 0.925 \\
\hline View UMass Ext. as important & 1.246 & 1.602 & $\begin{array}{l}3.546^{\mathrm{a}} \\
1.783^{\mathrm{b}} \\
0.415^{\mathrm{c}}\end{array}$ & $5.184 *$ \\
\hline $\begin{array}{l}\text { View other growers as important } \\
\text { Control variables from Gareau et }\end{array}$ & $\begin{array}{l}\text { 2.166 } \\
\text { l. }(2018)\end{array}$ & 1.519 & $3.050^{* * *}$ & $3.434 * *$ \\
\hline $\begin{array}{l}\text { Weather importance } \\
\text { Weather counts } \\
\text { Relative size of natural habitats } \\
\text { Education attainment } \\
\text { Age group }\end{array}$ & & $\begin{array}{l}4.020 * * * \\
1.647 \\
0.958 * \\
1.864 * * \\
0.422 * *\end{array}$ & & \\
\hline Female & & $5.277^{*}$ & & $\begin{array}{l}1.073^{\mathrm{a}} \\
5.821^{* * * b} \\
2.562^{\mathrm{c}}\end{array}$ \\
\hline $\begin{array}{l}\text { General conditions } \\
\text { Wetland habitat acreage } \\
\text { Upland habitat acreage }\end{array}$ & & & & $\begin{array}{l}2.504 * \\
1.104 * * \\
0.967 *\end{array}$ \\
\hline Constant & $0.040 * *$ & $0.0005 * *$ & $\begin{array}{l}0.398^{\mathrm{a}} \\
0.087^{*} * * \mathrm{~b} \\
0.051^{* * * \mathrm{c}}\end{array}$ & $\begin{array}{l}0.336^{\mathrm{a}} \\
0.018^{* * * b} \\
0.004^{* * * \mathrm{c}}\end{array}$ \\
\hline $\mathrm{N}$ & 89 & 74 & 90 & 77 \\
\hline McFadden's pseudo R-squared & 0.111 & 0.456 & 0.069 & 0.1216 \\
\hline
\end{tabular}

For the generalized ordered logit regression models of global warming worry, the dependent variable is an ordinal variable coded in this way: (1) not worry at all, (2) worry a little bit, (3) worry a fair amount, (4) worry a great deal. For variables that violate the proportional odds assumption: ${ }^{\mathrm{a}}$ odds of worrying at least a little bit rather than not worrying at all, ${ }^{b}$ odds of worrying at least a fair amount rather than worrying a little bit or less, ${ }^{\mathrm{c}}$ odds of worrying a great deal rather than worrying a fair amount or less

$* p<0.1 * * p<.05 * * * p<.01$ (two-tailed tests)

Next, we examine the relationship between the perceived importance of the ties to these three social network actors and the implementation of various climate adaptive management practices in cranberry production. The results are presented in Table 3. We do not find a significant association between the perceived importance of any of the three social actors and the number of management practices implemented. Moreover, whether a grower views the CCCGA, UMass Extension, or other growers as an important network tie is not associated with 1) whether this grower implements conservation or creation of pollinator habitat or 2) the degree to which a grower thinks management practices are important to their cranberry production. Most control variables, which are significant predictors of global warming attitude, are not associated with climate adaptive management practices. The only exception is the perceived importance of weather-related events, which is positively related to the perceived importance of management practices. 
Table 3 Results of regression models for three dependent variables on management practices: Massachusetts cranberry growers

\begin{tabular}{|c|c|c|c|c|c|c|}
\hline & \multicolumn{2}{|c|}{$\begin{array}{l}\text { Incidence rate ratios of } \\
\text { Poisson regression } \\
\text { models of management } \\
\text { practice count }\end{array}$} & \multicolumn{2}{|c|}{$\begin{array}{l}\text { Odds ratios of logistic } \\
\text { regression models of } \\
\text { pollinator habitat } \\
\text { conservation }\end{array}$} & \multicolumn{2}{|c|}{$\begin{array}{l}\text { Odds ratios of generalized } \\
\text { ordered logit regression } \\
\text { models of management } \\
\text { practice importance }\end{array}$} \\
\hline & Model 5 & Model 6 & Model 7 & Model 8 & Model 9 & Model 10 \\
\hline View CCCGA as important & 1.052 & 0.928 & 0.770 & 0.679 & 1.025 & 0.587 \\
\hline View UMass Ext. as important & 1.060 & 1.116 & 2.326 & 1.617 & 2.104 & 1.793 \\
\hline View other growers as important & 1.240 & 1.209 & 1.930 & 2.272 & 1.857 & 1.878 \\
\hline \multicolumn{7}{|c|}{ Control variables from Gareau et al. (2018) } \\
\hline General conditions & & 1.100 & & 1.225 & & 1.383 \\
\hline Weather importance & & 1.031 & & 1.276 & & $1.828 * *$ \\
\hline Weather counts & & 1.075 & & 1.000 & & 1.121 \\
\hline Education attainment & & 1.027 & & 1.114 & & 1.171 \\
\hline Age group & & 1.032 & & 1.357 & & 0.918 \\
\hline Female & & 0.827 & & 0.926 & & 2.149 \\
\hline \multirow[t]{2}{*}{ Constant } & $2.353 * * *$ & 1.423 & $0.197 * *$ & $0.012 * *$ & $2.040^{\mathrm{a}}$ & $0.105^{\mathrm{a}}$ \\
\hline & & & & & $0.254 * * b$ & $0.012 * * \mathrm{~b}$ \\
\hline$N$ & 91 & 79 & 91 & 79 & 85 & 75 \\
\hline McFadden's pseudo R-squared & 0.009 & 0.034 & 0.023 & 0.055 & 0.020 & 0.090 \\
\hline
\end{tabular}

For each of the three dependent variables, we have also estimated additional unreported models with different subsets of control variables, and found substantively similar results

For the Poisson regression models of management practice count, statistical tests suggest that there is no overdispersion

For the generalized ordered logit regression models of management practice importance, the dependent variable is an ordinal variable coded in this way: (1) somewhat important or less, (2) important, (3) very important. For variables that violate the proportional odds assumption: ${ }^{a}$ odds of considering management practices as important or very important rather than somewhat important or less, ${ }^{b}$ odds of considering management practices as very important rather than important, somewhat important, or less

$* p<0.1 * * p<.05 * * * p<.01$ (two-tailed tests)

\subsection{Content analysis of newsletters}

We acquired 104 newsletter issues: 44 issues of Bogside and 60 issues of the Cranberry Station Newsletter. The Bogside sample spans nearly four and a half years (from July 2015 to November 2019) and the Cranberry Station Newsletter spans nearly 10 years (from March 2010 to December 2019). The 100 most frequent words found in each sample are depicted in the illustrative word clouds in Fig. $1{ }^{4}$

The size of each word is positively correlated with the count of stemmed versions present in the two newsletter samples. (A full list of the top 15 words in each sample is given in Supplementary Table 2).

The mission of the UMass Extension Cranberry Station is "maintaining and enhancing the economic viability of the Massachusetts Cranberry Industry through research and outreach and serving the public welfare by supporting economic development and the protection of the

\footnotetext{
${ }^{4}$ This word cloud represents the 100 most common words in each newsletter sample. Words analyzed as "stemmed" ("use," "uses," "using," "used," etc.) are all coded under the most common word in the group. "Stop words" were automatically excluded from analysis. The words "cranberry," "CCCGA," "UMass," "Massachusetts," "United," "States," "page," and "508" (a telephone area code in eastern Massachusetts) were also excluded.
} 

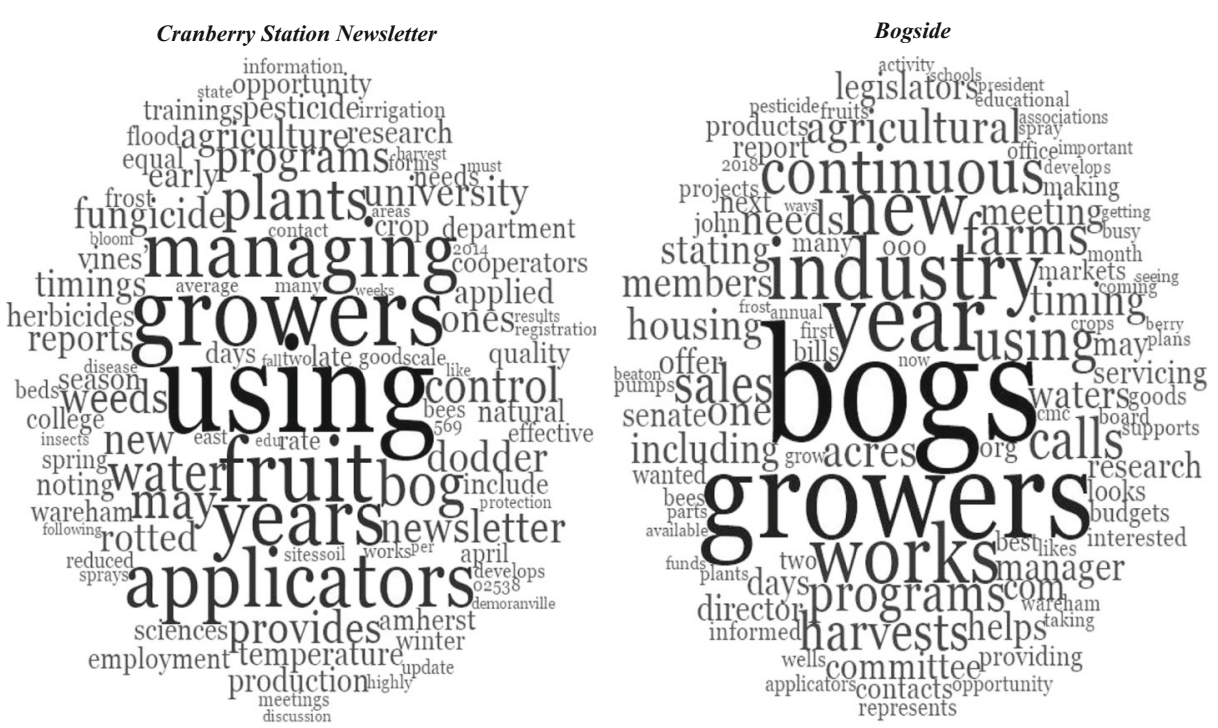

Fig. 1 Word clouds for UMass Cranberry Station Newsletter and CCCGA's Bogside: 100 most frequent words

environment" (ag.umass.edu/cranberry/cranberry-station). The first priority listed is "the economic viability of the Massachusetts Cranberry Industry"; the second priority, "serving the public welfare," is split into "supporting economic development" and "the protection of the environment." We therefore would expect the newsletters to reflect three priorities: economic success for the cranberry industry, the importance of economic development more generally, and environmental protection.

Consistent with this emphasis on economic viability, the Cranberry Station Newsletter largely discusses specific management-related issues and solutions that contribute to cranberry yield and economic viability. The top words in the Cranberry Station Newsletter sample confirm this; "using" is the number one word, while "applicators," "managing," and "control" are all included in the top 15. Common topics discussed in this newsletter are fruit keepingquality forecasts, updates on new trainings, information on pollination, pesticide application, frost management, and other specific problems affecting crop yields. The first priority in the mission statement, economic success in the cranberry industry, is the theme most clearly present in the data. The concerns and practices that are mentioned in this newsletterincluding issues like climate change, for example - are therefore likely to be framed in ways that support this goal.

The mission of the CCCGA is "to work to enhance the sustainability and profitability of CCCGA members" (https://www.cranberries.org/about). This statement differs from the UMass statement in its focus on serving the cranberry grower community specifically, rather than on economic growth or the public welfare in the abstract. Of the four management-related words in the UMass top 15 word list, "using" alone also occurs among the top 15 words of the Bogside sample. Bogside newsletters instead regularly include a number of social, historical, political, economic, and management-related sections - for example, the Cranberry Marketing Committee's "Updates from the CMC"; "Notes from the Hill," which highlights agriculturerelated news from the state capitol; and "Harvesting the Past: A Historical Look at the Cranberry Industry," which reprints stories of the early cranberry industry first published in "Cranberries" magazine. Various advertisements for products and upcoming events like 
meetings and festivals are often present as well. Bogside, therefore, is likely to include content which appeals to the grower's whole life, to a wide arrangement of communal conditions. The "About" page on the CCCGA website provides further confirmation, saying that the association "assists growers in solving everyday problems, offering assistance in regulatory compliance, sponsoring professional development seminars and organizing association activities..." (https://www.cranberries.org/about). Issues like climate change, therefore, we might also expect to be discussed in the context of how they can affect a grower's life - and their surrounding community - in a multitude of ways.

\subsubsection{Climate change newsletter references}

Both newsletters together contain fewer than 15 references to climate change during the sample periods examined (Bogside, 40 months; Cranberry Station Newsletter, 118 months). (For a full list of specific references, see Supplementary Table 3.) There are 11 climate change references in each newsletter sample, for a total of 22. Six of these mention climate change as a topic of discussion at an in-person event without further context, indicating that both the UMass Cranberry Station and the CCCGA hire speakers who address how climate change is impacting the cranberry industry. Just this information, however, does not provide the context necessary for analysis - how climate change is framed and discussed.

In the Cranberry Station Newsletter, after accounting for the in-person event references, five of the remaining eight frame climate change as an issue that exacerbates a specific cranberry-related problem that should be addressed with management practices or agricultural inputs. The December 2014 Cranberry Station Newsletter considers how to manage poison ivy, "a big winner in the climate change game since it responds positively to the increased $\mathrm{CO}_{2}$ in the atmosphere" (p. 6). The article suggests using Callisto ${ }^{\circledR}$, an herbicide. Similarly, the November 2015 and February 2016 issues of the Cranberry Station Newsletter mention climate change for its role in exacerbating the conditions that lead to fruit rot. Specifically mentioned is a "national document listing research priorities...towards the development of new and improved fruit rot management strategies" (Cranberry Station Newsletter, Nov. 2015: 4 and Feb. 2016: 6). Once again, climate change is framed as an issue to be addressed with practical management strategies. Even so, climate change is listed as a "low" priority issue rather than a cause for alarm (Cranberry Station Newsletter Nov. 2015: 4 and Feb. 2016: 6). The two references found in the December 2016 issue of the Cranberry Station Newsletter follow a similar pattern; both references are framed in the context of water management, where the focus is on recommending strategies such as heat mapping and late water treatments.

While Bogside also discusses climate change as a problem for cranberry production, the issue is framed more broadly, as a problem that requires engagement with complex environmental and social processes, not just agricultural inputs and management strategies. Bogside May 2016 explains that climate change is contributing to declines in native and commercially managed honey bee populations (Apis mellifera L.) that are vital for cranberry pollination (Bogside, May 2016: 16). This reference is made in the context of a specific cranberry-related topic - ensuring adequate pollination - but does not go on to provide a management or application-based solution. Instead, the problem discussed, the global pollinator decline, is presented as partially caused by agricultural applications and pesticides, not fixed with them.

The Bogside March and April 2018 issues also discuss climate change in the context of a complex socio-environmental problem. These issues include discussion of the Massachusetts Global Warming Solutions Act (GWSA) (Bogside, March 2018: 16 and Bogside, April 2018: 
16). GWSA was signed into law in 2008, "making Massachusetts one of the first states in the nation to move forward with a comprehensive regulatory program to address Climate Change" ("Global Warming Solutions Act"). Including this reference demonstrates that the CCCGA recognizes the political relevance of climate change action, and these examples thereby contribute to a message that climate change is a complex threat to both the cranberry industry and its growers. The most recent occurrences of the term climate change in the sample are in the Bogside issues of July 2019, September/October 2019, and November 2019. These references not only discuss climate change as a complex socio-environmental problem, but also emphasize the magnitude of the problem.

Bogside July 2019 contains an article written by the UMass Cranberry Station that lists climate change as one of the top three "drivers of change" in the cranberry industry (p. 26). Moreover, these "drivers of change" are identified as extremely complex issues that require help and insight not only from grower management and natural science, but from "19 academic disciplines" (Bogside, July 2019: 26). Similarly, in Bogside September/October 2019 , climate change is mentioned in an appeal to the growers to support funding for a 3year study on fruit quality. The CCCGA stresses that these fruit quality concerns will take collaboration among the whole industry to address:

"This will be a collaborative effort of industry, growers and researchers to collectively work towards developing solutions to a problem that is only getting more difficult with climate change and marketplace demands for high quality fruit" (Bogside, September/ October 2019: 8).

Bogside November 2019 continues this trend by including a quote from Senator Marc R. Pacheco (District of First Plymouth and Bristol). In this issue, the senator expresses his pleasure that cranberry operations in his district received "over $\$ 500,000$ though the Massachusetts Cranberry Bog Renovation Enhancement Grant Program” (p. 12). But he also states, "As the worst effects of climate change continue to emerge, our agricultural sector's need for infrastructure upgrades will only intensify" (Bogside, November 2019: 12). This example highlights both the increasing alarm that climate change is prompting and its complex interconnection with the political realm and the resources of the government.

The November 2019 Bogside issue includes a "Special Fundraising Appeal," in which the CCCGA highlights both the economic constraints on addressing fruit quality and the importance of recognizing that climate change will only continue to affect the cranberry industry in more adverse ways in years to come:

"We recognize the financial situation of our growers and that the timing of this fundraising effort is challenging at best. This will be a collaborative effort of industry, growers, and researchers to collectively work towards developing solutions to a problem that is only getting more difficult with climate change and marketplace demands for high quality fruit" (p. 19).

Once again, this Bogside item emphasizes that climate change must be addressed with collective action among industry, growers, and researchers, and not only through management strategies.

A third climate change mention in the November 2019 Bogside issue refers to the subject in similar fashion. The author of the article, Brian Wick, Executive Director of the CCCGA, notes that by using renewable energy, like solar, the cranberry industry can support climate mitigation practices like lessening dependence on fossil fuels. But he then goes on to say that 
not only cranberry growers, but also the wider community, must support these practices, and he expresses his frustration that this is often not the case.

\section{Discussion and conclusion}

In this study we examine how social ties to certain actors in their social networks affect cranberry growers' climate change attitudes and management practices in farming operations. Cranberry growers in Massachusetts, an essential farming community in the American and New England social, cultural, and ecological landscape, face a multitude of threats to their industry and livelihood in a world increasingly defined by global climatic change. We find that the perceived importance of the CCCGA, UMass Cranberry Station, and fellow cranberry growers in the eyes of the growers we studied is associated in nuanced ways with their climate change attitudes. When these connections amplify threat perception or worry, they can be considered "green ties," that is, ties with the potential to lead to collective action to combat climate change at the local level. Survey results indicate that the majority of growers view the grower's association (i.e., the CCCGA), extension service (i.e., the UMass Extension), and fellow cranberry growers as important actors in their social network. Only growers who view the CCCGA as important, however, are associated with higher odds of considering global warming a threat to their way of life. Viewing UMass Extension and a network of other growers as important, on the other hand, is associated with higher odds of feeling worried about climate change.

Like many growers in the United States, cranberry growers are somewhat predisposed to treat challenges related to weather conditions as an integral part of their everyday practices rather than as abnormalities to be attributed to anthropogenic climate change. Consequently, although cranberry growers might be concerned or worried about weather conditions, they are less likely to view them as an existential threat (see Gareau et al. 2018). Those who value the CCCGA, however, overcome this predisposition. As our statistical analysis illuminates, growers who identify the CCCGA as an important actor in their social network are more likely to acknowledge that they believe climate change is a "threat" to their "way of life." One possible reason for this may be that the CCCGA disseminates information that contributes to and encourages communal conditions conducive to considering climate change a threat, as our content analysis of the newsletter Bogside reveals. If a grower identifies the CCCGA as important to their network, this can reasonably be considered an indication of a grower's trust in this organization as a source of important information. As supported by our content analysis of Bogside, the CCCGA frames climate change as an important issue in wider environmental and communal conditions and provides a rather consistent and clear picture of the threat created by global climate change.

Even if growers may feel threatened by the impacts that climate change poses for certain aspects of their farming operations, this does not necessarily translate into feeling "worried" about its effects. One possible reason for this is a disposition in which a person acknowledges that climate change is a serious threat, but believes that it will, in time, be effectively addressed by human innovation. This sentiment was expressed by a longtime key actor in the cranberry community, former director of the UMass Cranberry Station, Dr. Carolyn DeMoranville, in a 2007 article in The Christian Science Monitor. DeMoranville referenced climate change while discussing the UMass Cranberry Station's efforts to create cranberry hybrids. She warned that these developments on fruit type might not be adequate to deal with the possible future effects 
of climate change, but she also expressed optimism that human developments will address the problem:

"If we're talking about numerous degrees of difference in 50 years, that may be beyond working with the tools we have. But presuming that somebody decides to finally start doing something about climate change, then I think we would still have the tools...to deal with the amount of change that's predicted in the less-drastic models" (Azios 2007).

This existential threat, in contrast, is less often highlighted in the Cranberry Station Newsletter, which focuses on immediate, practical issues threatening cranberry production, such as pests and weeds, rather than broader concerns related to political, economic, or global climatic conditions. This helps explain why the perceived importance of UMass Extension is not associated with growers' recognition of climate change as a threat to their way of life. This is not to say that the CCCGA is more concerned about climate change. The UMass Cranberry Station, for example, authored a powerful article about climate change in July 2019, but it had it published in CCCGA's Bogside. If a grower were only to read the Cranberry Station Newsletter, therefore, they would not necessarily receive this message.

The CCCGA, in short, seems to be the more powerful social actor with regard to promoting "green ties" within the growers' social network. Through Bogside, growers gain access to a knowledge frame that conveys the global scientific community's position that climate change is a threat. The CCCGA transmits its knowledge frame among actors in the cranberry community, creating social conditions in which concern for climate change among growers is evident. The UMass Cranberry Station generates a different knowledge frame in which worry over climate change is expressed among its networked growers, though this tie does not generate the recognition of climate change as an existential threat. The difference between "worry" and "threat to the way of life" might have something to do with the different ways these powerful actors influence the cranberry growing community.

It is noteworthy that the social ties among cranberry growers that foster communal conditions supporting worry about climate change parallel the ties created by the UMass Cranberry Station. Although growers may feel threatened by the impacts that climate change can have on certain aspects of their growing operations, this does not necessarily translate into feelings that climate change threatens their "way of life" or that they feel "worried" about it. Social ties among growers, therefore, might lead to different interpretations of climate change depending on the specific dispositions of the growers in their network. For example, the "personal conditions" of gender and age of other growers with whom they are connected were found to be significant predictors of climate change attitudes (see Gareau et al. 2018).

This analysis also sought to discover whether certain social networks are associated with the adoption of management practices that address climate change. We find that climate change attitudes are, to various degrees, associated with cranberry growers' ties to important social actors (i.e., ties to the CCCGA, UMass Cranberry Station, and other cranberry growers), yet none of the perceived importance of these powerful actors is associated with the actual implementation of climate adaptive management practices. This finding suggests that both the CCCGA and UMass could refine and strengthen their outreach to growers regarding climate change mitigation and adaptation strategies. For example, although both newsletters discuss many different management techniques, including those that could be considered climate adaptive strategies, none of the references to climate change found in these samples emphasizes these types of practices. 
It is important to acknowledge the limitations of our findings on a couple of levels. For one, the statistical analyses were conducted based on 91 survey responses, which is a relatively small sample. As noted in the methods section, however, our sample accounts for roughly one quarter of the population of cranberry growers in Massachusetts, which makes it an adequate sample for statistical inference about the population (Salant 1994). Nonetheless, the power of hypothesis testing is limited by the small sample size, especially in models that include additional control variables. We partially mitigated this issue by using an alpha level of 0.1 and, when applicable, more parsimonious models, such as the generalized ordered logit regression models, over other alternatives. We are also limited to trusting the growers when they report to us that certain actors are indeed important to them. Moreover, it is challenging to determine in our survey data the strength of the social interactions between the cranberry growers and these three social actors. Whether growers in the survey attended the many UMass Cranberry Station meetings, thoroughly read each and every monthly Bogside or Cranberry Station Newsletter issue, or routinely engaged in activities with fellow growers is not directly captured in the survey. Our findings, however, suggest that the connection between growers and the CCCGA is strong enough to create a pattern of influence on climate change perceptions among growers connected to this powerful actor, which is also supported by participant observation and in-depth interviews not reported in detail in this paper. Second, allowing growers to self-report the importance of certain actors creates a potential for endogeneity and might impose a limitation on the research findings concerning network ties. We are confident, though, that self-reported importance is worth discussing, mainly because it is widely understood among growers and researchers that CCCGA, UMass Cranberry Station, and grower networks are all important actors in this tightly knit, growing community. As a unique growing community of only 400 or so in number, cranberry growers rely heavily on their networks to remain viable in this struggling industry. Our findings suggest that connections to CCCGA are raising awareness among growers about the connections between those struggles and climate change. Finally, there are limitations to the ways we introduce management practices to the growers. By limiting the count of management practices to activities undertaken in the past 5-10 years, the measure systematically excludes individuals who may have taken certain long-term actions more than 10 years ago. We focused on this time span so that the survey results matched the time frame of the newsletters included in our content analysis, which extends to years in the Cranberry Station Newsletter.

Social networks are clearly an integral aspect of understanding cranberry grower attitudes and actions toward climate change. As the example of DeMoranville's comment in The Christian Science Monitor cited earlier suggests, the CCCGA and UMass Cranberry Station's official communications are also augmented by the climate discussions that powerful actors in these networks have in the mass media. A November 2012 USA Today article titled "Global Warming Targets Thanksgiving," for another example, quotes Brian Wick, the current CCCGA Executive Director, saying, "The growers are at the point where there's concern that the climate is changing. We are seeing these sort of extremes in weather" (Montgomery 2012). Or again, a 2015 Cape Cod Times article titled "Climate Change: Heat May Drive Cranberry Industry North," which cites both DeMoranville and Wick; DeMoranville expresses concern for recent patterns of "big rain events with long dry periods in between," and says, "Eventually, if it got hot enough, you would come to a time when you couldn't grow cranberries" (Fraser 2015). However, the article reports, neither DeMoranville "nor Wick see that happening anytime soon" (Fraser 2015). These examples show that there are key actors in these social networks who are willing to discuss 
climate change as a threat, although, as with our newsletter findings, they do not necessarily advocate for immediate collective action.

In sum, identifying the CCCGA as important is associated with greater odds of perceiving climate change as a threat, and identifying the UMass Cranberry Station as important is associated with greater odds of worrying about climate change. This illuminates a need for these social actors to work together more closely to foster more powerful green ties bridging their disparate connections to climate attitudes. Although these organizations already collaborate to an extent (for example, Bogside often includes a section written by the UMass Cranberry Station), our findings highlight that these two organizations represent two distinct fields of knowledge in the cranberry industry. The technical focus of the UMass Cranberry Station seems to complement the socioeconomic and sociopolitical focus of the CCCGA. However, when it comes to encouraging growers to consider climate change as a serious threat to their way of life - a threat calling for immediate action - their differing knowledge frames for now seem to prevent a deeper connection and interdependence with one another that could more consistently and forcefully convey what needs to be done about the impact of climate change on the cranberry industry. Climate change needs to be framed as a problem that is vast and socio-environmental (Givens et al. 2019; Huang 2018), but also one with many tangible effects on specific, local processes (Adger 2003). By avoiding both social and natural reductionist thinking, this framing enables an understanding of climate change that allows the severity and complexity of the problem to be expressed, and acted upon (White et al. 2016, 2017). This complexity must be reckoned with if cranberry grower livelihoods are to survive the already occurring and increasingly alarming threats that climate change poses to the cranberry industry.

Acknowledgments The authors are grateful to the two reviewers for their insightful comments, to Adelaide Mickelson for her help with the literature review, and to the UMass Cranberry Station and the Cape Cod Cranberry Growers' Association for allowing us to solicit participation in our survey through their networks and for helping us access their newsletters. Researchers wishing to access our survey data may contact the first author or the Boston College Office for Research Protections at IRB@bc.edu.

\section{References}

Adger WN (2003) Social capital, collective action, and adaptation to climate change. Econ Geogr 79(4):387-404

Agricultural Marketing Resource Center (2019) Cranberries. Retrieved December 22, 2019 (https://www.agmrc. org/commodities-products/fruits/cranberries)

Armstrong C (2016) Cranberries and a changing climate. Presented at the University of Maine Cooperative Extension: Pest Management Office, Orono, ME

Azios T (2007) Cranberries are headed north. Christian Science Monitor, November 21

Ballet J, Sirven N, Requiers-Desjardins M (2007) Social capital and natural resource management: a critical perspective. J Environ Dev 16(4):355-374

Bodin Ö, Crona BI (2009) The role of social networks in natural resource governance: what relational patterns make a difference? Glob Environ Chang 19(3):366-374

Bourdieu P (1985) The forms of capital. In: Richardson JG (ed) Handbook of theory and research for sociology of education. Greenwood Press, Westport, pp 8-21

Cape Cod Cranberry Growers' Association (2019) Where tradition meets innovation. cranberries.org. Retrieved December 22, 2019 (https://www.cranberries.org/history)

Cape Cod Cranberry Growers' Association (2020) About Cape Cod Cranberry Growers Association. Retrieved July 17, 2020 (https:/www.cranberries.org/about) 
Chatrchyan AM, Erlebacher RC, Chaopricha NT, Chan J, Tobin D, Allred SB (2017) United States agricultural stakeholder views and decisions on climate change. Wiley Interdiscip Rev Clim Chang 8(5):e469

Chong D (2014) Explaining public conflict and consensus on the climate. In: Wolinsky-Nahmias Y (ed) Changing climate politics: U.S. policies and civic action. CQ Press, Los Angeles, pp 110-145

Crona B, Hubacek K (2010) The right connections: how do social networks lubricate the machinery of natural resource governance? Ecol Soc 15(4):18

Deressa TT, Hassan RM, Ringler C, Alemu T, Yesuf M (2009) Determinants of farmers' choice of adaptation methods to climate change in the Nile Basin of Ethiopia. Glob Environ Chang 19(2):248-255

Dunlap RE, McCright AM, Yarosh JH (2016) The political divide on climate change: partisan polarization widens in the U.S. Environ Sci Policy Sustain Dev 58(5):4-23

Fafchamps M (2006) Development and social capital. J Dev Stud 42(7):1180-1198

Fitzmaurice C, Gareau BJ (2016) Organic futures. Yale University Press, New Haven

Fraser D (2015) Climate change: heat may drive cranberry industry north. Cape Cod Times, October

Gareau BJ (2008) Class consciousness or natural consciousness? Socionatural relations and the potential for social change. Rethink Marx 20(1):120-141

Gareau BJ (2010) A critical review of the successful CFC phase-out versus the delayed methyl bromide phaseout in the Montreal protocol. Int Environ Agreements 10(3):209-231

Gareau BJ (2012) Worlds apart: a social theoretical exploration of local networks, natural actors, and practitioners of rural development in southern Honduras. Sustainability 4(7):1596-1618

Gareau B (2013) From precaution to profit. Yale University Press, New Haven

Gareau BJ, Huang X, Gareau TP (2018) Social and ecological conditions of cranberry production and climate change attitudes in New England. PLoS ONE 13(12):e0207237

Givens JE, Huang X, Jorgenson AK (2019) Ecologically unequal exchange: a theory of global environmental injustice. Sociol Compass 13:e12693

Global Warming Solutions Act (2008) Background. Enacted by Senate and House of Representatives in the 191st General Court of the Commonwealth of Massachusetts. Retrieved December 23, 2019. (https://malegislature.gov/Laws/SessionLaws/Acts/2008/Chapter298)

Hesse-Biber SN (2010) Mixed methods research. Guilford Press, New York

Hoang LA, Castella J-C, Novosad P (2006) Social networks and information access: implications for agricultural extension in a rice farming community in Northern Vietnam. Agric Hum Values 23(4):513-527

Hollenbach SJD (2002) The common good and Christian ethics. Cambridge University Press, Cambridge

Hsieh H-F, Shannon SE (2005) Three approaches to qualitative content analysis. Qual Health Res 15(9):12771288

Huang X (2018) Ecologically unequal exchange, recessions, and climate change: a longitudinal study. Soc Sci Res 73:1-12

Jackson LE, Wheeler SM, Hollander AD, O'Geen AT, Orlove BS, Six J, Sumner DA, Santos-Martin F, Kramer JB, Horwath WR, Howitt RE, Tomich TP (2011) Case study on potential agricultural responses to climate change in a California landscape. Clim Chang 109(1):407-427

Jones N, Sophoulis CM, Iosifides T, Botetzagias I, Evangelinos K (2009) The influence of social capital on environmental policy instruments. Environ Polit 18(4):595-611

Keough G (2018) Massachusetts cranberry production forecast down 1 percent from 2017. National Agricultural Statistics Service

Knowler D, Bradshaw B (2007) Farmers' adoption of conservation agriculture: a review and synthesis of recent research. Food Policy 32(1):25-48

Liu Z, Smith WJ, Safi AS (2014) Rancher and farmer perceptions of climate change in Nevada, USA. Clim Chang 122(1-2):313-327

Lowitt K, Hickey GM, Ganpat W, Phillip L (2014) Developing communities of practice in support of resilient value chains for sustainable food security. World Dev 74:363-373

Lucier CA, Gareau BJ (2015) From waste to resources? Interrogating 'race to the bottom' in the global environmental governance of the hazardous waste trade. J World Syst Res 21(2):495-520

McCright AM, Dunlap RE (2011) The politicization of climate change and polarization in the American public's views of global warming, 2001-2010. Sociol Q 52(2):155-194

McCright AM, Dunlap RE, Xiao C (2014) Increasing influence of party identification on perceived scientific agreement and support for government action on climate change in the United States, 2006-12. Weather Clim Soc 6(2):194-201

Montgomery J (2012) Global warming targets thanksgiving. USA Today, November 22

Mossler MV, Bostrom A, Kelly RP, Crosman KM, Moy P (2017) How does framing affect policy support for emissions mitigation? Glob Environ Chang 45:63-78

National Research Council (2010) Advancing the science of climate change. The National Academies Press, Washington, D.C. 
Olson K, Gareau BJ (2018) Hydro/power? Politics, discourse and neoliberalization in Laos's hydroelectric development. Soc Dev 4(1):94-118

Ostrom E (2000) Social capital: a fad or a fundamental concept? In: Social capital: a multifaceted perspective. World Bank Publications, Washington DC, pp 172-214

Playfair S (2014) America's founding fruit. University Press of New England, Lebanon

Pretty J (2003) Social capital and the collective management of resources. Science 32:1912-1914

Running K, Burke J, Shipley K (2017) Perceptions of environmental change and climate concern among Idaho's farmers. Soc Nat Resour 30(6):659-673

Salant P (1994) How to conduct your own survey. Wiley, New York

Sanginga PC, Kamugisha RN, Martin AM (2007) The dynamics of social capital and conflict management in multiple resource regimes. Ecol Soc 12(10):6

Straus JR (2014) Federal holidays: evolution and current practices. U.S. Congressional Research Service, Washington DC

Takemura K, Uchida Y, Yoshikawa S (2014) Roles of extension officers to promote social capital in Japanese agricultural communities. PLoS ONE 9(3):e91975

van Deth JW (2010) Participation in voluntary associations: dark shades in a sunny world? Am Behav Sci 53(5): 640-656

van Rijn F, Bulte E, Adekunle A (2012) Social capital and agricultural innovation in sub-Saharan Africa. Agric Syst 108:112-122

White D, Rudy A, Gareau BJ (2016) Environments, natures, and social theory. Palgrave/Macmillan Press, New York

White DF, Gareau BJ, Rudy AP (2017) Ecosocialisms, past, present and future. Capital Nat Social 28(2):22-40

Williams R (2016) Understanding and interpreting generalized ordered logit models. J Math Sociol 40(1):7-20

Yaméogo T, Fonta W, Wünscher T (2018) Can social capital influence smallholder farmers' climate-change adaptation decisions? Soc Sci 7(3):33

Publisher's note Springer Nature remains neutral with regard to jurisdictional claims in published maps and institutional affiliations. 